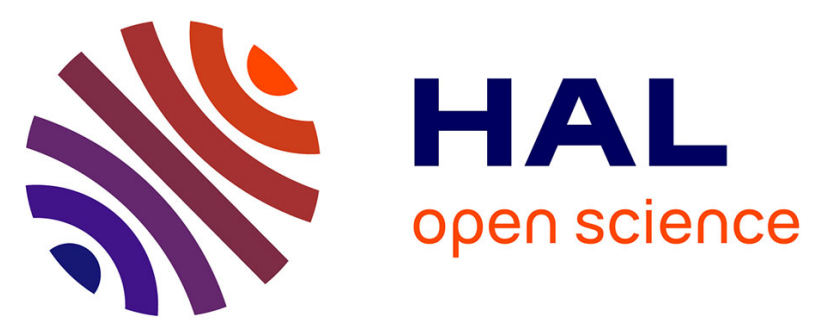

\title{
The Experiences and Personal Religious Beliefs of Egyptian Science Teachers as a framework for understanding the shaping and reshaping of their beliefs and practices about Science-Technology-Society (STS)
}

Nasser Mansour

\section{To cite this version:}

Nasser Mansour. The Experiences and Personal Religious Beliefs of Egyptian Science Teachers as a framework for understanding the shaping and reshaping of their beliefs and practices about ScienceTechnology-Society (STS). International Journal of Science Education, 2008, 30 (12), pp.1605-1634. 10.1080/09500690701463303 . hal-00513345

\section{HAL Id: hal-00513345 \\ https://hal.science/hal-00513345}

Submitted on 1 Sep 2010

HAL is a multi-disciplinary open access archive for the deposit and dissemination of scientific research documents, whether they are published or not. The documents may come from teaching and research institutions in France or abroad, or from public or private research centers.
L'archive ouverte pluridisciplinaire HAL, est destinée au dépôt et à la diffusion de documents scientifiques de niveau recherche, publiés ou non, émanant des établissements d'enseignement et de recherche français ou étrangers, des laboratoires publics ou privés. 


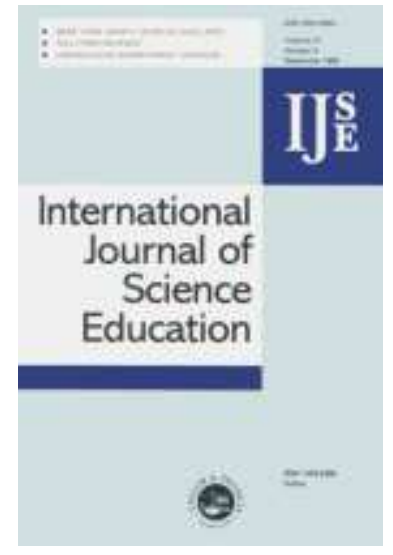

\section{The Experiences and Personal Religious Beliefs of Egyptian Science Teachers as a framework for understanding the shaping and reshaping of their beliefs and practices about Science-Technology-Society (STS)}

\begin{tabular}{|r|l|}
\hline Journal: & International Journal of Science Education \\
\hline Manuscript ID: & TSED-2007-0097 \\
\hline Manuscript Type: & Research Paper \\
\hline Keywords: & $\begin{array}{l}\text { in-service, qualitative research, science education, teacher beliefs, } \\
\text { teacher actions }\end{array}$ \\
\hline Keywords (user): & $\begin{array}{l}\text { Teachers' Personal religious beliefs, Teachers' Beliefs and Practice, } \\
\text { Science, Technology, and Society (STS) }\end{array}$ \\
\hline
\end{tabular}

\section{s scholaroNE" \\ Manuscript Central}


This research investigates the role of experience in relation to teachers' beliefs and practices. The study adopted a social-cultural constructivist perspective using an interpretive approach. The research was guided by teachers' interpretations of their experiences related to teaching science through Science-Technology-Society (STS) issues. These interpretations are re-interpreted to find meaningful conceptual categories (grounded in the data) from which to build a model to understand the influence of experiences within socio-Islamic culture on teachers' beliefs and practices. Data was collected from ten teachers using interviews and observations. The findings of this study suggest that it was mainly teachers' personal religious beliefs and experiences that shaped their beliefs and practices. The research also led to a model, constructed on the basis of the data analysis, which suggests an explanation of how teachers' personal religious beliefs and experiences influence their beliefs and practices.

Personal religious beliefs; Egyptian science teachers; Teachers' experiences; Religious schema; Teachers' beliefs and practices; Pedagogical beliefs, Science; Technology and Society (STS); social context; Teacher education

\section{Introduction}

Teachers' beliefs develop throughout their lifetimes and are influenced by a variety of factors, including events, experiences, and other people in their lives (Knowles, 1992). Some beliefs are directly adopted from the culture, while others are shaped by experiences framed by the culture. For example, each individual shares similar experiences as a child, as a member of a family, and as a parent. These experiences shape teachers' beliefs about students, curriculum development, and the overall schooling process (McGillicuddy-De Lisi \& Subramanian, 1996). 
Shulman (1987) concluded that teachers' beliefs come from four sources: accumulated content knowledge, educational materials and structures, formal teacher education, and the 'wisdom of practice', i.e., from practical experience. Lortie (1975) suggested that teacher education and classroom teaching experience contribute to the development of pedagogical content knowledge, while disciplinary knowledge in teacher education helps to develop curricular and subject matter knowledge among prospective teachers. Richardson (2003) identified three major sources for teachers' beliefs: personal experience, experience with schooling and instruction, and experience with formal knowledge, including school subjects and pedagogical knowledge. He emphasised that experience with schooling and instruction was the most important formal source for teachers' beliefs since they had been students in formal schools for many years. In addition, informal experiences are represented in the contacts that teachers have had, or have, in every-day life, and that might have some influence by adding to, refining, adjusting, supporting, challenging, or even changing their beliefs and knowledge. In this respect, Zeichner (1980) labelled such informal and formal experiences as 'socialisation influences', arguing that teachers' own experience of having been taught at school had a stronger influence on them than their formal university training.

The kind of experience that a teacher has undergone makes him/her act in a certain manner e.g. conduct a certain classroom activity, or undertake a professional development activity. Beliefs have been described as filters through which all new information must pass and which are used to interpret new experiences (Kagan, 1992) and Pajares (1992) suggests that beliefs are created through a process of enculturation and social construction. Butt et al. (1992) argue that in order to understand how a 
A growing body of research argues that teachers' beliefs should be studied within a framework that recognises the influence of culture (Barnes, 1992; Hamilton \& Richardson, 1995, Olson, 1988). Within the socially-constituted nature of culture, the personal religious beliefs of individuals are likely to play an integral role in producing, filtering, prioritising and interpreting information (Fysh \& Lucas, 1998). Thus, the context in which scientific concepts are presented to students may be strongly influenced by the teacher's beliefs or worldview (Cobern \& Loving, 2000).

World events have shown that religion can have a profound impact on many societies, and that an individual's religious beliefs can certainly influence his/her own actions. Therefore, religious influences on the lives of contemporary teachers should be considered when building up an understanding of their work in the classroom. The influence of religion on a teacher's practices will be significant, especially if he/she has to respond intelligently and effectively to the challenges of a science curriculum that includes certain controversial issues which may occupy part of the science/religion spectrum (Fysh \& Lucas, 1998). Particularly where Islam is concerned, religion is a major element of the culture; thus religious influences on the lives of contemporary teachers should be taken into account when forming an insight into their experiences, and their related beliefs and practices. The influence of personal religious beliefs on the development of the beliefs and practices of any 
teacher will be significant, but this influence may be especially important in the area of science, technology and society (STS) because of the complexity of the topics handled.

Most studies of beliefs in general, and of STS in particular, have been carried out in Western societies rather than Islamic cultures. Many topics included in STS education are acknowledged as controversial; e.g., issues concerning evolution, cloning, abortion, and genetic engineering. These pose problems for science teachers in Islamic countries, because of potential conflict between the implications of a scientific study of some these issues and the religion of Islam. Some other issues may not conflict formally with Islam but teachers' experiences, or the way they interpret the Islamic view regarding these issues, can create what is, in fact, a false contradiction. This paper describes a study of teachers' experiences, beliefs, and practices about STS issues within Islamic culture. The main research question is, "What influences have affected or shaped science teachers' beliefs and practices about STS education?" To answer this question, the study poses three sub-questions;

- What variety of experiences influences teachers' beliefs and practices?

- What is the role of experiences in shaping teachers' beliefs and practices?

- What is the role of the Islamic context in shaping teachers' experiences, beliefs and practices?

\section{The Educational System in Egypt}

Two separate educational systems exist in Egypt. One is secular, and is a system for technological, practical, specialized training, while the other, Al-Azhar is based on spiritual and cultural instruction. Science has been part of the central National 
Curriculum (NC) since the 1960s, and has traditionally included integrated science at primary and preparatory levels, and separate science - chemistry, physics and biology - at the secondary level. This study focused on science teachers working in preparatory-secular schools (see Table 1).

\section{Table 1. The Secular Education System in Egypt}

\section{Theoretical framework}

This study is not about the influence of Islam as a religion on teachers' beliefs and practices. Rather, it is concerned with the influence of teachers' understanding and interpretation of religious principles on the teaching and/or learning of controversial scientific issues, and the extent to which a person views these issues as directly or indirectly related to religion. This is why the research linked the word 'personal' with the concept 'religious beliefs' - thus Personal Religious Beliefs (PRB). This term is used to refer to the views, opinions, attitudes, and knowledge constructed by a person through interaction with his/her socio-cultural context through his/her life history and interpreted as having their origins in religion. The PRB works as a framework for understanding events, experiences and objects on an individual level. It is a social construct based broadly on the various experiences (and more particularly on the religious experiences) that a person lives through. Since PRBs are a product of the interactions among all the experiences that the person accumulates, and depend on the socio-cultural context in which the individual has been brought up, this study adopted social-cultural constructivism as its theoretical framework.

\section{Methodology}


The research had two stages. In the first, the data collection method was developed and participants were identified. The second involved collecting data by interviews and observations, analyzing the data using Multi-Grounded theory, discussing and interpreting the data, and finally developing a model for understanding the shaping and reshaping of teachers' beliefs and practices about STS.

\section{Participants}

Since it is interpretive-qualitative research, 'generalisability' was not a primary concern (Lofland \& Lofland, 1984) and the sample was chosen on theoretical grounds (Glaser \& Strauss, 1967) rather than a concern with 'representativeness' (Miles \& Huberman, 1998). A 'maximum variation strategy' (Patton, 2002) was used to select a sample for study. The study started with six teachers and expanded to ten teachers until data collection revealed no new data (Charmaz, 2006). The selection was based on their diverse beliefs about teaching science through STS issues as revealed in responses to a questionnaire, which had been completed as part of another study by the author (Author 'anonymous for review process', 2006). The questionnaire consisted of 57 items and used a combination of Likert-type scales, ranking and openended questions. It is included the following sub-scales:

- Beliefs about the relationship between science and technology

- Beliefs about the relationship between science and society, beliefs about the relationship between technology and society

- Beliefs about interaction between science-technology-society.

- Beliefs about goals of science education

- Beliefs about teaching/learning science through STS issues

- Beliefs about teaching STS issues 
- Beliefs about the roles of teacher/students in teaching/learning STS issues and use of teaching strategies.

The sampling was designed to include a broad variety of informant experiences, based on gender (five males and five females), age (from mid-30s to the early 50s), Variety of teaching expertise (from 10 to 23 years of teaching) and their experience of teaching in different preparatory schools in Egypt's Gharbiyya governorate. All ten teachers were Sunni Muslims (as are the majority of Muslims in Egypt) whose religious beliefs are founded on the Qur'an and the collected sayings (ahadith) of the Prophet Muhammad. They are represented in this study by letters (A, B, C, D, E, F, G, H, I and J).

\section{Data Collection Methods}

Data were collected in the first semester of the 2004-2005 academic year by means of a semi-structured interview and qualitative observation.

\section{Interviews}

Most of the interview questions were prepared in advance by considering the relevant literature (Bybee \& Mau, 1986; Aikenhead \& Ryan, 1989; Rubba \& Harkness, 1993; Poulson, et al., 2001; Levitt, 2001; Tsai, 2002), and were piloted with two Egyptian preparatory teachers. The order of the questions was modified and some questions were added or varied as the interviews unfolded. The wording of the questions was also varied to ensure that participants grasped the meaning. The interviews were audio-taped and were transcribed immediately after the interview. Transcripts were given to each of the teachers before the start of the next interview for their scrutiny, 
confirmation or criticism. Following each interview an initial analysis was carried out to inform subsequent interviews. All the interviews lasted approximately 30-45 minutes, and each interviewee had around 4 to 5 observations and interviews. In grounded theory, data collection continues until theoretical saturation is reached (Strauss \& Corbin, 1998). During the fourth interviews, responses showed repetition of the emerging analytical categories. By the end of the fifth interview, core categories seemed to be saturated suggesting that little new information or insight would be gained by additional interviewing.

\section{Classroom observations}

The study adopted qualitative observation, whose origins lie in anthropology, because it produces detailed-qualitative descriptions of human behaviour that illuminate social meaning and shared culture (Foster, 1996). Classroom observation aimed to ascertain the extent to which teachers' classroom practices were affected by their beliefs (Drever, 2003) and to provide an insight into how their beliefs affected their observed practice (Bell, 1993). Since the study focussed on STS issues, teachers were observed teaching some units from the curriculum content, based mainly on STS issues1.

\section{Data Analysis}

The main aim of this research was to build a theory or a model to understand how teachers' beliefs are shaped or reshaped and to ascertain the role of teachers' experiences and personal religious beliefs in this shaping process. A theory is a particular type of interpretive framework, and qualitative data analysis involves a

\footnotetext{
${ }^{1}$ For example, lessons were chosen from Unit 1 ('Environment and its Resources') in the first preparatory level book, entitled Science and the Future, and from Unit 2 ('Environmental Balance and Variation') in the second preparatory level book, entitled You and Science.
} 
number of systematic procedures and techniques for developing and testing theories. The principles of grounded theory were adapted in this study to build a theory or model.

Grounded theory (GT) offers a pure approach, in contrast to a theory-driven deductive analysis. Stem (1980) pointed out that grounded theory provided a method for investigating previously unrehearsed areas. This makes the case for theory generation stronger than the case for theory verification. The original grounded theorists warned against reading literature concerning other theories before performing data collection and data analysis (Glaser \& Strauss, 1967: 37). GT has been criticised for this pure emergent procedure (Ezzy, 2002; Goldkuhl \& Cronholm, 2003; Lind \& Goldkuhl, 2005). In particular, development of an isolated theory, as in GT, does not take acknowledge that the development of acknowledge is a cumulative process. Goldkhul \& Cronholm (2003) argued that it was important to relate an evolving theory to relevant research during the generation process since this could improve the theory. In this study, a Multi-Grounded Theory (MGT) approach which involves both 'empirical grounding' and 'theoretical grounding' was used to analyse the data. MGT is a sophisticated model of grounded theory that deepens both inductive and deductive methods of theory generation (Ezzy, 2002).

Analysis of the data occurred in two stages (Figure 1). Stage One, the 'theory generation stage' aimed to develop 'empirical theory' based mainly on the data. The processes of this stage, which mostly followed GT, included:

1. Inductive coding which corresponds to open coding in GT; 
2. Conceptual refinement where critical reflection on empirical statements is conducted;

3. Building categorical structures which involves combining categorises into theoretical statements corresponding to axial coding in GT) and

4. Theory condensation, which matches selective coding in GT.

Stage Two, the 'Explicit grounding Stage' was based on matching the empirical theory with existing theories in the literature related to the phenomenon being studied.

\section{Figure 1. Procedures for generating the Personal Religious Beliefs model using Multi-Grounded Theory}

To avoid repetitiveness in describing the data analysis procedures, the following section (data analysis and discussion of the results) also explains how GMT was used during the process of data analysis and theory generation. The evolution of the PRB model is presented in two integrated sections. The first ('Data results - developing the empirical theory') introduces the development of the study's codes, and the second ('discussion of the study - the evolving theory') shows how the PRB model that was developed matches existing theories.

\section{Data results and developing the empirical theory}

Table 2 exemplifies the first stage of the analysis and outlines how the theoretical coding of 'personal religious beliefs' emerged from the data. The initial process of data analysis was done inductively by using an incident-to-incident coding technique (Charmaz, 2006) (see some examples of the open coding in Table 2). In 'conceptual refinement', the second process of the analysis, a critical stance was adopted to 
examine the views that participants had expressed. At this point, which was a very important stage in the data analysis, every category that was developed was reflected upon with regard to its ontological status (Lind \& Goldkuhl, 2005). The main aim as stated above was to understand the role of experiences in general, and of religious experiences in particular, in shaping teachers' beliefs and practices.

Related to this was the attempt to understand how the teachers interpreted these experiences and how they functioned on the basis of this understanding. To deal with such a critical position, the ontological categories of the socio-instrumental pragmatism framework (Goldkuhl \& Cronholm, 2003) were used. These categories include: human inner worlds (knowledge, intentions, emotions, interest, etc); human actions; intervention-as-action; interpretation-as-action; reflection-as-action; symbolic objects (signs); artefacts (artificially-made material objects and their processes); and natural environment (objects and processes). This stage indicated that that interpreting and evaluating an experience was common among the participants and that participants also had a commitment to act on, or carry out their interpretation (see some examples of the 'the conceptual refinement' process in Table 2).

The third process of the data analysis was building categorical structures (an axial coding), in which categories are combined into theoretical statements. In this stage, the data analysis focused on understanding how the categories related to each other, as well as on defining the direction of the relationship from one category to other. In comparing and linking the categories with one another, I was guided by what Glaser called "the Six Cs: Causes, Contexts, Contingencies, Consequences, Covariances, and Conditions" (1978: 74). For example, what are the relationships between the different 
kinds of experiences? Which is the most influential kind of experience? What are the consequences of that predominant category on the other categorises? Under what conditions do teachers form positive or negative religious experiences? In what context do teachers form religious experiences?

To achieve the aim of this stage, I adapted a socio-pragmatic approach in MGT, based on 'the action paradigm model' defined by Strauss and Corbin (1998), who stated that grounded theory was an action and an interactional method of theory building. They used several generic notions related to action explanations, such as causal and intervening conditions, context, action/ interactional strategies, and consequences. Pettigrew (1989) claimed that this provided an opportunity for examining continuous processes in context, in order to draw out the significance of various levels of analysis and thereby reveal the multiple sources of loops of causation and connectivity, so crucial to identifying and explaining patterns in the process of change. This process of coding revealed that teachers were influenced by three kinds of experience: teacher education at university, past school experience, and out of school experience mainly concerned with family (see 'building categorical structures' in Table 2).

\section{Table 2. Emergence of the theoretical coding 'Personal Religious Beliefs'}

The data also showed that knowledge of STS came mainly from informal sources, while personal religious beliefs were associated with different aspects of teaching/learning STS issues. These included religious epistemology, personal religious views about science, personal religious views about the curriculum, personal religious views about the aim of science, personal understandings of religion, personal religious views about teaching and learning STS and the characteristics of Muslim 
science teachers. The main subcategorises related to teachers' beliefs about teaching/learning STS issues included the epistemology of science, teaching/learning STS issues, the science curriculum and teachers' roles and practices. Some practices were consistent with beliefs, while others were inconsistent.

In contrast with MGT procedures proposed by (Goldkuhl \& Cronholm (2003:11) in which the 'condensing theory' process is carried out during the 'explicit grounding stage' the condensing categories process, or 'theoretical coding', was conducted during the stage of developing empirical theory. At the explicit grounding stage, the theory was neither ready nor sufficiently stable to confront other theories. Condensing categories at an early stage of its development ('building categorical structures') might have destroyed the theory or, at the very least, influence the way it was developed. Instead 'theoretical coding' as described by Glaser (1978) was used to investigate the possible relationships developed between categories in the 'building categorical structures' before the 'matching theory' process was begun. Some of Glaser's theoretical coding families were used in this process; these included analytical categories such as 'social contexts', 'consequences', 'identity' and 'cultural'. Glaser (1978) explains that these codes serve as units of analysis but connote emergent, rather than structural properties. This stage ended with the production of an 'empirical theory', which was ready now to be matched with the existing theories. The analysis indicated that five main categorises emerged from the data. These were: teachers' personal religious beliefs; teachers' social contexts; teachers' experiences; teachers' pedagogical beliefs; and teachers' practices. The analysis also showed that on the whole, teachers' beliefs were shaped by many sources of experience including teacher education, in-school life experiences, "past 
school experiences", out-of-school life experiences, and personal religious beliefs. The latter was one of the strongest determinants of teachers' beliefs and practices.

Theory diagrams were used to present the 'empirical theory' model or theory (see Figure 2). These diagrams can be seen as models of the focused issue and its action context (Axelsson \& Goldkuhl, 2004). In the theory diagrams, the research used different labels to indicate the role of each category within the action chain, such as 'precondition' or 'action'. These labels were derived from the action-oriented model. In this way, the theory diagram gave a more distinctive picture of the preconditions, actions, results, and effects associated with its action focus (Axelsson \& Goldkuhl, 2004).

\section{Figure 2. A 'Theory diagram' illustrating the sequence of the main categories} 'empirical theory'

The relationships between and evidence for these main categories is illustrated by examples of the verbatim quotations from the transcripts which are set out below in two parts. These show how the teachers' pedagogical beliefs were influenced by the formal and informal learning experiences, which shaped their Personal religious beliefs, and how, in turn, these beliefs influenced their actual practices.

\section{Part One: Personal religious beliefs and teachers' formal and informal experiences}

Personal religious beliefs and science teacher education 
He further clarified:

What I understand about these issues is that there is a relationship between science and religion but where is the role of teacher education here? (T/C)

Teacher $(\mathrm{F})$ added:

When we went to do our school practice, we faced situations that were different from those, which we were trained for, especially when we started to teach something like cloning, which is sensitive and is related to our religious beliefs. We got nothing from university or in-service training. (T/F)

Participants also criticized the university courses. Teacher B noted:

Before I started at the university, I expected to study science from a religious perspective. That never happened. However, I put a lot of effort into collecting information and verses from the Holy Qur'an so that I could explain the values and morals behind learning science to my students. (T/B)

Other participants indicated that university staff influenced their beliefs about science:

The professors of chemistry and physics from the Faculty of Science made me like science and believe in its value. Those professors were models for me because they devoted their lives to studying phenomena in the laboratory, and they also persisted in getting us to apply what we had learnt. For instance, a physics professor used to say to us, "As a physics teacher you should be capable of repairing any broken machine in your house..... Our Islamic religion motivates us to help others without expecting to get something back... Our prophet Muhammad taught us that God supports people when they help other. (T/F)

Personal religious beliefs and past school experiences

Other participants indicated that school teaching staff influenced not only their beliefs about science but also the way they later taught science to their students: 
Here teacher E commented:

The model I never forget is Mrs [name deleted by researcher] who taught us biology and who used to relate science to religion. On one occasion she taught us how important water is for everything. Here teacher $\mathrm{E}$ read a verse from the Qur' $\mathrm{an}^{2}:$ "...God has sent down water down from the sky. "With it have We produced diverse pairs of plants each separate from the others" [Qur'an 20: 53]. She also read the verse: "And Allah has created every animal from water...." [Qur'an 24:45].

Then she added:

I did like this way of teaching. I took her as a model for my own teaching, I do believe that everything is found in the Holy Qur'an and it is very easy to make the students understand or like science by using this Islamic approach to teaching science, especially with regard to controversial issues. (T/E)

Teacher G gave another example:

I remember my biology teacher at secondary school. She was a fantastic teacher; as students we all liked her. So I imitated not just her teaching style but also the way that she dealt with the students. (T/G)

In reply to my question about the ways in which her teacher was fantastic, she added:

She used to simplify the controversial issues and discuss them from different aspects - religiously, scientifically, and socially. (T/G)

Personal religious beliefs and life-out-of-school experiences

The analysis revealed that early-out-of school experiences were potentially influential

in shaping teachers' beliefs about learning and teaching STS. Teacher B saw his

family as having a major effect on his teaching and his dealings with his students:

\begin{abstract}
My parents are religious people. They brought me up according to the concepts of respect for the opinions of others, equality, responsibility, teamwork, trust, and patience. So, when I teach a lesson like 'pesticide use', which can be a controversial issue, I try to be objective, and stress to all my students that we should give everybody a chance to express his views freely and that all opinions are important. I try to teach my student what I learnt from my family - which is how to argue any controversial issue. (T/B)
\end{abstract}

\footnotetext{
${ }^{2}$ The English translations of the Qur'anic Verses are based on Ali (2004).
} 
My father used to bring us honey and encourage us to eat it every day. He told me about the benefits of the honey which are mentioned in the Holy Qur'an and which scientists discovered much later. He used to read to us from the Qur'an: "And Your Lord taught the Bee to build its cells in hills, on trees, and in (men's) habitations" [Qur'an 16: 68] "Then to eat of all the produce (of the earth), and find with skill the spacious paths of its Lord: there issues from within their bodies a drink of varying colours, in which is healing for men: verily in this there is a Sign for those who give thought" [Qur'an 16: 69]

Teacher (A) then explained how this had influenced his attitude toward teaching/ learning science:

\begin{abstract}
As a result of this, I started to question the relationship between the Qur'an and science, and between science and society, and when I became a science teacher I started to use that approach in my teaching. I found it an influential approach, especially in making the students learn science and have a positive attitude toward science. (T/A)
\end{abstract}

\title{
Part Two: the teachers' Personal Religious Beliefs and their relationship to pedagogy and practice
}

Joint analysis of the interviews and the classroom observations revealed that teachers' beliefs regarding the epistemology of science, their roles, the students' roles, the aims of science and their teaching methods were strongly shaped by, and intertwined with, personal religious beliefs.

Personal religious beliefs and epistemology of science

Islamic-religious experiences clearly influenced teachers' views concerning the nature and purpose of science. Science was not perceived as a divine revelation but as a means of promoting the wellbeing of humankind and providing a better understanding of the creation of Allah. Teacher (F) said:

What I know about ' $I l m$ ' [science] is that it means knowledge and we study it because our religion, 'Islam' encourages us incessantly to pursue knowledge. For 
example in the Qur'an, Allah ordained His servants to pray to Him thus: "High above all is Allah, the King, the truth! Be not in haste with the Qur' an before its revelation to you is completed, but say, O my Lord! Advance me in knowledge". [Qur'an 20: 114] (T/F)

Teacher (I) views Islam as:

.... religion based upon knowledge, for it is eventually knowledge of the Oneness of God, combined with faith and total confidence in Him that saves man. (T/I)

I asked her why she chose inquiry to be her best way of teaching science. In reply she said:

The wording of the Qur'an is full of verses inviting man to use his mental powers, to wonder about things, to think, and to know, since the goal of human life is to discover the truth. (T/I)

Teacher $(\mathrm{H})$ had a remarkable view about the relationship between science and religion:

Science... shouldn't be subordinate to culture but at the same time it shouldn't contradict religious concerns. If such a contradiction appears, it is merely an apparent contradiction that results from a misunderstanding of the scientific phenomenon of the religious text. The religious text is stable and untouchable. Thus, if science contradicts religion, the scientist should review the phenomenon and try to understand it correctly. Science can change a society's culture but not its religion. Rather, science can help people understand religion. $(\mathrm{T} / \mathrm{H})$

And, as teacher D remarked:

Scientists throughout the world should study the Holy Qur'an as their starting point. The Qur'an is full of scientific meanings. (T/D)

Personal religious beliefs and beliefs about teaching/learning

Teachers' personal religious beliefs or their interpretation of Qur'anic views clearly influenced their pedagogical beliefs, which in turn, powerfully affect their practices. 
The main consideration is our society is an Islamic one. For this reason, I should initiate the lesson on cloning with an Islamic introduction beginning with the Qur'anic verse that there should be husbands and wives or males and females. While I am explaining the lesson, I will confirm that we can take from cloning what is positive and leave what is negative. What is positive is that we can use cloning with plants and other living things rather than with humans. (T/C)

Cloning is very dangerous to the human being and to society. I am not happy to teach this issue at all. However, if I have to, I will present the Islamic view regarding the idea behind reproductive principles. This is based on the union of the mother's ovum and the sperm of her legally married husband....The best teaching methods will be lectures. So, I can be on the safe side and won't upset religion or put myself in hell. Religion comes first, then science. (T/J)

Religion is the basis for evaluating controversial issues. This is because science is changing while religion remains constant... If science and religion conflict with regard to a given issue, religion should win. (T/A)

Teachers' personal religious beliefs also influenced their learning aims and how they achieved them. Teacher (D), for example, said:

My main aim for an issue like cloning will be to analyse and show the students the scientific information on cloning, as well as evaluating the moral and ethical implications associated with it [cloning] from an Islamic point of view. (T/D)

Teacher (D) suggested this sequence for teaching this issue:

I will discuss with the students their definition of cloning and we write down their definitions on chart paper. Next, I get the students to debate their own positions on the cloning issue. I talk to the students about what they already know on the subject of cloning. We discuss what things have already been cloned and what they think will be cloned in the future. (T/D)

I asked her what the main point was that she wished to make. She explained this as follows: 
The science curriculum should be designed on the basis of the scientific events presented in the Holy Qur'an; it should also be based on the principles of our Islamic religion and should omit any controversial issues that are against Islam.... Sometimes, I feel really concerned about having to teaching these controversial issues. I am very religious. It worries me when I'm teaching that these issues are going to have a negative influence on the students' religious beliefs. If I can I will leave it to teachers who teach religion. (T/B)

Two teachers expressed a contrasting view:

Teaching means dealing with controversial issues that are also very interesting issues. By teaching such issues we have the chance to teach our students the correct view of the relation between Islam and science. I consider this to be a form of religious education, which is my duty as a Muslim, and I think it is the main role of teaching science as well. (T/C)

If there is a contradiction with scientific theories, such as 'evolution theory', the curriculum should present this clearly and support the Islamic view, using Qur'anic verses, towards such issues to teach our students the relationship between science and Islam. We can also teach them how they can argue a point. $(\mathrm{T} / \mathrm{I})$

\section{Teacher $(\mathrm{H})$ criticised the current science curriculum:}

We should have our own science curriculum. The science curricula that we have now are filled mostly with western scientists. We have Muslim scientists too, and 
we should give our students Muslims scientists as models who they can emulate. $(\mathrm{T} / \mathrm{H})$

Issues related to teachers' roles

Teachers' personal religious beliefs influence their views about their own and their students' roles in the classroom.

I don't listen to the students' opinions regarding this issue [cloning] because the students don't have sufficient information about it. [Furthermore] in such controversial lessons, the teacher's role is to correct the students' misconceptions from the Islamic perspective. (T/C)

Some teachers tried to shape students' attitudes and opinions to concur with their own understanding of religious views:

If the opinion relates to religion, there is no controversy about it. A religious belief is presented directly. Away from religious affairs, the teacher shouldn't impose his opinions on the students. I don't voice my opinion myself, so students can express their own views freely without being influenced by the opinion that I give. Of the opinions of scientists, I present only the opinions that conform to our religion and society. (T/A)

\section{Personal religious beliefs and classroom practices}

Observations by teachers on science lessons that were based mainly on STS content, indicated that personal religious beliefs affected their practices in relation to pedagogical beliefs in general, and subject-specific pedagogical beliefs in particular. For example, one used co-operative learning to teach STS issues such as education about 'drugs':

... because I wanted them to feel and learn the concept of co-operation as it comes in the Holy Qur'an (T/F)

She recited a verse from the Qur'an about help and co-operation between people: 


\begin{abstract}
"Help you one another in righteousness and piety, but help you not one another in sin and rancour; fear Allah; for Allah is strict in punishment" [Qur'an, 5: part of verse 2].
\end{abstract}

Most of the teachers tried to start their science lessons with an appropriate verse (from the Qur'an) or ahadith (sayings of the Prophet). For example, when he taught the unit about 'water', and in order to explain the idea that water was one of the most valuable natural elements on Earth, teacher B mentioned that God had said,

“We made from water every living thing” [Qur'an 21: part of verse 30]

In another lesson on 'the Atom', teacher A wrote the following verse on the blackboard at the beginning of the lesson:

\begin{abstract}
"The unbelievers say," never to us will the hour": Say, "Nay! But most surely, by my Lord, it will come upon you - by Him who knows the unseen - from whom is not hidden the least little atom in the heavens or on earth: nor is there anything less than that, or greater, but is in the record perspicuous" [Qur'an 34:3].
\end{abstract}

Coloured chalk was used to highlight these words from the verse: 'atom', 'weight', 'nor greater' and the teacher said that in light of modern scientific findings, "the smallest possible part of matter" was called a molecule, and began to explain the structure of an atom by pointing to the words 'less than' in the verse. He said that this meant that an atom included all particles, discovered or undiscovered:

I mean by 'discovered', nuclei, electrons and protons. And by 'discovering', I mean that by developing and advancing or through tools and methods of research, more parts or characteristics can be discovered in the future which we don't yet know.

Then he began to go through the verse in detail, relating it to the subject of the lesson, although:

...'greater than that' - that includes chemical compounds, which I will discuss later. 
"See you not that Allah makes the clouds move gently, then joins them together, then makes them into a heap? Then will you see rain issue forth from their midst. And He sends down from the sky mountain masses (of clouds) in which is hail: He strikes with it whom He pleases and He turns it away from whom He pleases. The vivid flash of His lightning well-near blinds the sight" [Qur'an, 24:43]

At the end of the lesson, teacher $(\mathrm{H})$ told students that the Holy Qur'an contained all knowledge about the universe. So when it was necessary to understand their environment they also need to understand the Holy Qur'an very well. Also, water should be protected from pollution. He reminded them that the Prophet had lived in a harsh desert environment, where water was equal to life. As a gift from God, water is the source of all life on earth, as is confirmed in the Qur'an:

\footnotetext{
"Do not the unbeliever see that the heavens and the earth were joined together (as one unit of creation), before We split them apart? We made from water every living thing. Will they not then believe" [Qur'an 21:30]
}

Teacher $(\mathrm{H})$ also pointed out that the Qur'an constantly reminded and encouraged individuals to keep water clean and not to abuse it, and in this connection mentioned these verses: 


\begin{abstract}
“See you the water which you drink?" [Qur'an 56: 68];
“Do you bring it down (in rain) from the cloud or do We?" [Qur'an 56:69]; and

"Were it Our will, We could make it salt (and unpalatable): then why do you not give thanks?" [Qur'an 56:70].
\end{abstract}

\title{
Discussion and Theoretical grounding of the Personal Religious Beliefs (PRB) Model
}

This section presents the 'explicit grounding stage' of the multi-grounded theory approach. Using a theory matching process, the empirically derived theory 'the Personal Religious Beliefs (PRB) Model' (see Figure 2) was compared with theories found in the literature. This process was used to seek internal and external validation of the PRB Model (Goldkuhl \& Cronholm, 2003) and was an interactive comparison of the derived theory with existing theories.

During this 'theory diagrams' were used to generate of the PRB model as shown in Figure 3 arrows were used to represent the relationship between two concepts or two categories, and the direction of the influence of one on the other. Bold arrows showed the strong influence of one component on another one. The matching of the dimensions of a PRB model with the existing theories is presented using the same sequence that was used to present the data analysis. It begins with the relationship between teachers' personal religious beliefs and their experiences and ends with the relationship between teachers' personal religious beliefs and their practices.

The dimensions of the developed model include:

- Personal religious beliefs, teachers' experience and teachers' interpretation; 
- Teachers' interpretations of their experiences and the forming of their pedagogical beliefs;

- Teachers' pedagogical beliefs, their framework for action and practice;

- Knowledge and teachers' beliefs and

- Teachers' identity as a product of the interaction between their personal religious beliefs, experiences, pedagogical beliefs and practices.

The following paragraphs explain these dimensions and match the dimensions of the PRB Model with the existing theories.

Personal religious beliefs, teachers' experiences and teachers' interpretation

Analysis of the interviews together with the classroom observations revealed that teachers' beliefs regarding their roles, students' roles, the aims of science and their teaching methods were strongly shaped by personal religious beliefs derived from the values and instructions inherent in the religion. The present study found that teachers' personal religious beliefs worked as a 'schema' which influenced what was perceived (McIntosh, 1995). McIntosh defined a schema as "a cognitive structure or mental representation containing organized, prior knowledge about a particular domain" (1995: 2). He also noted that schemas were built via encounters with the environment 'social context' and could be modified by experience.

The religious schemas of these teachers influence the way they perceive new experiences. Teachers arrange the elements of their social context to reflect the organisation of their own personal religious beliefs or religious schemas. A teacher with personal religious beliefs or religious schemas is more likely to force a religious interpretation on experience than a teacher without such personal religious beliefs or 
religious schemas. Moreover, teachers with particular personal religious beliefs may understand the situation or the experience very differently from those without these personal religious beliefs. However, teachers also hold beliefs about themselves, the nature of science, the individual students, teaching and learning science through STS, the nature of the discipline they teach (e.g. STS issues), the social context in which they live, the school environment in which they work, and the constraints they have to deal with. These beliefs, in turn, work through the lens of past experiences, since they are translated into teacher practices within the complex context of the classroom.

The findings indicated that experiences prior to teaching STS issues had shaped what Pinar (1978) called 'the architecture of self', and in turn affected their practices. In this respect, Butt et al (1992) view an individual's 'architecture of self' (i.e., the private person) as predominantly influenced and shaped by experiences of context and situation. In turn, in a cyclic manner, the way a person acts in a situation and a context may shape and influence it. The present study also supported the idea that teachers' life experiences and backgrounds affected what they believed, the way the interpret and interact with their social context (Woods, 1987) and consequently the way they taught (Clark \& Peterson 1986). Studies of the origins of teachers' beliefs indicate that life experiences are a major contributor to the formation of beliefs (Richardson, 1996). In this respect, Budd Rowe (1996) elaborated further on the idea that the attitudes, beliefs and feelings formed by past experiences could have a significant impact on the way in which a teacher might misinterpret the meaning of a situation. This would result in a warped version of the strategy that failed to provide the type of learning experience that was intended. 
The study found, furthermore, that teachers' personal religious beliefs controlled the gaining of new knowledge and experiences. Ball-Rokeach et al (1984) proposed that a person's value-related attitudes towards objects and situations and the organisation of values and beliefs about self, formed a comprehensive belief system that provided an individual with a cognitive framework, map, or theory. In this respect, the models explaining the influence of experiences on teachers' beliefs and practices (e.g., Knowles, 1992) are largely supported by the findings of this study, which established that early and teacher-education 'formative experiences' were initially interpreted by individual teachers through their religious beliefs.

In addition, analysis of the interviews showed that teachers' personal Islamicreligious beliefs embraced their beliefs about what science is, what science should be for, what STS they should and should not teach, and how STS should be taught. Data analysis found that personal religious beliefs acted as a filter for new experiences; i.e., teachers' understanding or interpretations of Islamic religious beliefs worked as the criteria or bases for interpretations of the new experiences. In this case, teachers' understanding of religion determined their understanding of what early experiences meant to an individual at the time of an event. The findings indicated that other family, daily life and school experiences were analysed through the lens of teachers' personal religious beliefs. So, through such beliefs, each teacher had some values that s/he used to evaluate knowledge that had to be accepted and actions that had to be taken.

The influence of personal religious beliefs on other kinds of experience is represented in Figure 3 by bold arrows that point from 'personal religious beliefs' to 'teachers' 
experiences' as well as to shaping teachers' beliefs and practices. The developed PRB model also shows that personal experiences can affect teachers' personal beliefs. However, the interactive influence between teachers' experiences and their personal religious beliefs is not equal. Personal religious beliefs are the stronger influence.

\section{Teachers' interpretations as a link between the experiences and beliefs}

The study supported the idea that teachers were not just simply formed or socialized by their lifetime experiences; they were, in fact, active participants in interpreting these experiences (Sexton, 2004). According to Knowles (1992), the particular interpretation assigned to an experience was transformed to a 'schema', which he defined as "a way of understanding or a cognitive filter and a basis for teacher-centred classroom practices" (1992: 138). In the present study the term 'instructional schema' meant a settled system of pedagogical beliefs following the process of filtering by teachers' previous religious beliefs and experiences. In this respect, the results of the present study coincided with the arguments of Knowles and Holt-Reynolds (1991) that teachers' prior experiences had moulded their educational thinking, and that through the interpretations of these experiences, teachers formed the beliefs that they used directly to evaluate their own teaching practices. In this vein, there is a substantial body of literature that highlights the relationship between teachers' beliefs and their thinking. Beliefs are taken to be psychological constructs that portray the organization and content of a teacher's thinking which, in turn, influence a teacher's interpretation of experiences and actions (Kagan, 1992; Nespor, 1987; Pajares, 1992; Enyedy et al, 2006). 
The findings of the study also agreed with Knowles (1992) that the interpretation and subsequent schema developed by an individual with regard to classroom practices and other relevant experiences, was highly idiosyncratic; individuals experiencing a singular event would have multiple perspectives on that event. The schema or settled beliefs determine the manner in which teacher might take certain steps, so that the schema becomes an evaluative tool for examining teacher practices and is transformed into a framework for action. As the study shows, teachers who view science as a body of knowledge rely on textbooks to assist them in transmitting science knowledge. Also, a teacher who believes that science is merely a body of knowledge to be acquired will have a very different approach to teaching science from one who believes science is a way of making sense of the world, of asking questions and seeking answers, of observing and exploring.

These findings concur with Richardson (1996) who found that teachers' beliefs were among the major constructs driving teachers' ways of thinking and classroom practices. Johnson (1992) reported research on literacy teaching that supporting the notion of beliefs tending to shape teachers' instructional practices. That conclusion was also supported by Schoenfeld (1998), who claimed that teachers' beliefs shaped what they perceived in any set of circumstances, what they considered to be possible or appropriate in those circumstances, the goals they might establish in those circumstances, and the knowledge they might bring to bear in them. So far, the developed PRB Model (Figure 3) has highlighted the idea that teachers' interpretation is the link or the transmitter between teachers' experiences and has formed teachers' beliefs. The PRB model also shows that interactive relationships either between 
'teachers' experiences' and 'teachers' interpretations', or between 'teachers' interpretations' and 'teachers' beliefs' are in fact Reciprocal relationships.

\section{Teachers' pedagogical beliefs, their framework for action and practice}

The analysis and interpretation of data on the process used by teachers to transfer teacher beliefs into practice, found that teachers tended to use the history of their own schooling and in particular, specific teacher role models to guide their own practices. Maslovaty (2000) noted that a teacher's belief system, crystallised through a cultural context, resulted in the development of different educational ideologies. Maslovaty also found that teachers' social value orientation contributed to the choice of strategy to cope with socio-moral dilemmas (in the present study, the choice of strategy is called 'framework for action'). However, transforming this framework of action into real practice in the classroom depended on other contextual factors, e.g., constraints, school environment, teachers' personal religious beliefs and experiences, and teacher's identity.

This conclusion was supported by Talbert and McLaughlin (1993) who defined the 'context effect' as a notion implying that conditions such as policies, resources, curricula, goals, values, norms, routines and social relations in the school influenced teaching and learning outcomes. The PRB model presents the idea of a 'framework for action' to indicate that teachers intend to enact their beliefs in the classroom. It also makes clear that other factors limit or facilitate the operation of teachers' plans or frameworks for action. Figure 3 shows a reciprocal interaction between teachers' practices and the future framework of action. 


\section{Knowledge and teachers' beliefs}

The powerful influence of teachers' beliefs in general or teachers' personal religious beliefs in particular on gaining knowledge related to STS or controversial issues was highlighted by the findings. However, the settled or developed teachers' beliefs 'schema' acted as an information organizer and priority categoriser, and in turn controlled the way it could be used. In the interactions between knowledge and beliefs, beliefs controlled the gaining of knowledge and knowledge influenced beliefs. This suggested that teachers needed to create their own STS knowledge through a process of interaction between their existing beliefs and knowledge base, and the new ideas with which they came into contact (Richardson, 1997). Dadds (1995) and Lichtenstein, McLaughlin and Knudsen (1992) suggested that increased content knowledge went hand in hand with increased confidence, while having knowledge about teaching carried its own kind of authority that had the potential to empower teachers. This highlighted the significant role of teacher education in involving STS topics in the current teacher education programme. As shown in Figure 3, there is a reciprocal interaction between teachers' beliefs and knowledge on one hand, and between teachers' experience and knowledge on the other.

Teachers' identity as a product of the interaction among their personal religious beliefs, experiences, pedagogical beliefs and practices

The study's findings concurred with those of Cole (1990) and Knowles (1992) that a teacher's role identity was determined by early family experiences, being young students, teacher role models, previous teaching experiences, and other significant prior experiences. However, the current study added teachers' personal religious beliefs as one of the main formative influences on teachers' identity. As long as a 
teacher's experience changes daily, his/her identity changes sequentially. This conclusion agrees with Yerkes (2004), who claimed that, "Identity is not set in stone". Identity is always changing. A teacher's experiences play an essential role in his or her identity. Each teacher has different experiences, which is what makes all teachers unique. Thus, identity and identity construction are ongoing processes.

Concerning the dynamic relationship between teachers' identity, experience, beliefs and context, the study agreed with Wenger (1998) who pointed to five salient aspects of identity: (1) identity is related to one's personal history; (2) one's identity is also related to one's experience as negotiated within the context of existing cultural practices, complete with their categories and cultural histories; (3) identities are related to membership in communities; (4) people are members of multiple communities and thus one's identity is at the nexus of these multiple memberships; and (5) one's identity at a given moment is an interaction between local and global contexts. This formulation provides bridge between the intensely personal nature of teaching and its very public and cultural aspects.

\section{Figure 3. Personal Religious Beliefs (PRB) Model}

Not only do different experiences, and the belief systems that are subsequently formed, create the basis for teacher role identity; they also determine the (negative or positive) orientation of that identity. This study also suggests that the nature of teacher role identity (whether negative or positive) determined the extent of the influence on the teacher of social constraints or the school environment. The findings further indicated that pedagogical beliefs and practices were influenced by the results of the interaction between teacher's identity, and social constraints, or school 
environment. If a science teacher who has a positive teacher role identity works in a school environment which there are many constraints (e.g. pressure of examinations, large classes, lack of resources, students' family background, lack of time, school administration, etc.), his/her expected practice might be negative traditional practices or a mix of traditional and constructivist practices. The PRB Model (Figure 3) shows that teacher identity is a social product of the interaction among personal religious beliefs, teachers' experiences, teachers' beliefs and teachers' practice. However, teachers' personal religious beliefs produced the strongest influence on forming teachers' identity.

Teachers (I) and (F) offered a notable example of the relationship between teacher role identity and teachers' beliefs and practices. Although teacher (I) faced many constraints on her practice, to some extent she practised as an 'inquiry strategy' when teaching STS issues. This could have been due to her strong identity. However, stronger role identities were associated with inquiry practices within these contextual realities. In the case of teacher $(\mathrm{F})$, although she too faced many problems (e.g. lack of resources, time, and pressures of examination system) when teaching STS issues using co-operative learning, to some extent the administrative system, and especially her colleagues, offered a flexible environment. She was given extra time with her classes and sometimes colleagues exchanged their classes with her so that she could have two consecutive periods (110 minutes in total) with one class. Thus, teachers with strong-positive teacher role identities are better able to deal with the barriers to implementing innovative practice that teachers have to face.

\section{Implications of the present study}


This study confirmed that, in the case of teaching science through Science, Technology and Society, science teachers bring their cumulative-interactive experiences to the teacher education programme, training programmes, and the workplace, both in and out of school (Britzman, 1986; Woods, 1987). It is essential that teacher educators elicit and explore these experiences, and the beliefs and practices that accompany them (Davies \& Rogers, 2000). The findings stressed the dynamic relationship between teachers' identity, religious experiences, and pedagogical beliefs and practice. In addition, the study showed that as the experience of the teachers changed day by day, their identity changed sequentially. These findings have implications for the planning and organization of both pre-and in-service teacher education.

Experience in teacher education was also shown to be a crucial element in the development of teachers' professional identities. The PRB model developed by the present study offers a framework for teachers' professional development which may be of value to educational institutions that are moving towards a "conceptual change" approach to teacher education (where teacher experiences and beliefs are taken as the starting point for introducing new concepts or pedagogies).

The study findings showed how the interaction amongst experiences was a significant factor in understanding the relationship between teachers' beliefs and practices and how such experiences could shape teachers' identities and in turn, affect their orientations and practices in the science classroom. Thus, an important activity for teacher education will be to understand in-service or pre-service teachers' experiences in general and their religious experiences in particular and to explore their teacher 
The study also indicated that most of the teachers' religious experiences related to teaching controversial issues were from informal sources (family, previous teachers, the media, etc.). Educational decision makers and science educators around the world should be made aware that teachers' personal religious beliefs are a highly effective variable that can have a positive or negative influence on the entire educational process. It was also shown that teachers' personal religious beliefs could be considered a positive factor in developing positive attitudes among teachers towards science and teaching science. It is therefore suggested that decision makers, curriculum developers and science educators should engage in thoughtful reflection and discussion about developing various study programmes. These would act as formal knowledge sources about the relationship between science and religion and would also train teachers how to debate issues related to science and religion.

The study's findings suggested that teachers sometimes created a false contradiction between Islam and science due to their individual interpretations of the nature of Islam and science. For many people, there is no separation between religion and all aspects of life, and, as is well-known, Islam is not only a religion but a way of life. 
Poole (1996) argued that compatibility was needed between religious education and science education. In cultures where religion has a major influence on people's lives the development of science curricula should be made in a partnership between science educators and religion scholars, especially with regard to social-scientific issues associated with religion. This process would provide opportunities to challenge teachers' personal religious beliefs, to introduce appropriate perceptions of religous attitudes, and to leave the door open for different views and different understandings.

The role of personal religious beliefs and experiences in understanding teachers' beliefs and practices was highlighted in the study's findings. However, there is still a need for a deep understanding of how teachers, through experiences in their private lives and professional contexts, have acquired these personal religious beliefs. This could be done through biographical inquiry, a research approach that helps to make sense of teacher's individual experience and personal religious beliefs and enables discovery of the educational significance and the quality of such experience through its relation to previous and later experiences (Butt et al, 1992).

\section{A Final Word}

As stated previously, the argument of this study is not about the influence of the Islamic religion on teachers. Rather it is about teachers' understanding of the Islamic religion and their enactment of this understanding in the science classroom. So, there is a need for regular investigation of teachers' and students' personal religious beliefs to guide them to the right way, as their religion tells them. 
There is no doubt that Islam encourages science and the gaining of knowledge. Nor is there any need to defend the Islamic position on knowledge or research. Islam came to educate and to benefit people's lives. There is no better illustration of the close links between Islam and knowledge than statements of the Prophet Muhammad, who said that:

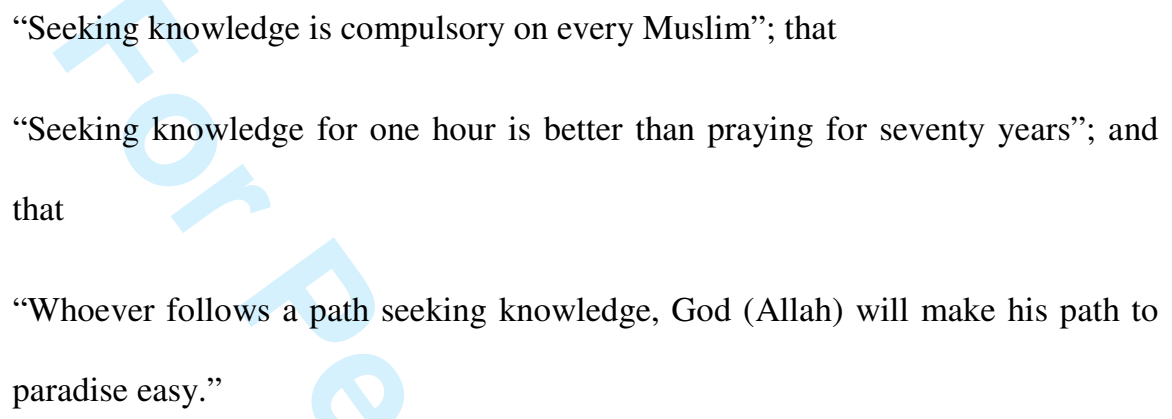

\section{Acknowledgements}

I would like to thank Keith Postlethwaite, Nigel Skinner and Jack Priestley for their helpful and valuable comments on earlier drafts of this manuscript. I would also like to thank the two anonymous reviewers for their insightful comments which were helpful in redirecting of the manuscript.

\section{References}

Adams, P., \& G. Krockover (1997). Beginning Science Teacher Cognition and Its Origins in the Pre-service Secondary Science Teacher Program. Journal of Research in Science Teaching, 34 (6), 633-653.

Aikenhead, G. \& A. Ryan (1989). The development of a multiple choice instrument for monitoring views on science-technology-society topics. Saskatoon, Canada: University of Saskatchewan, College of Education.

Ali, Yusuf (2004). The meaning of The Holy Qur'an: English translation. Birmingham: Islamic Dawah Centre International. 
Author, (anonymous for review process) (2006). The mediating factors between Egyptian science teachers' beliefs and practices concerning teaching science through Science-Technology-Society (STS): Implication for science teacher education, paper presented at the annual conference of the British Educational Research Association (BERA) at the University of Warwick, UK, 6-9 September.

Axelsson, K. \& Goldkuhl, G. (2004). Theory Modelling-Action focus when building a Multi-Grounded Theory. Accepted to the $3^{\text {rd }}$ European Conference on Research Methods in Business and Management (ECRM).

Ball-Rokeach, S., M. Rokeach, \& J. Grube (1984). The Great American Values Test. New York: Free Press.

Barnes, D. (1992). The significance of teachers' frames for teaching, In T. Russell \& H. Munby (eds.), Teachers and Teaching: From Classroom to Reflection. (pp. 9-32). London: the Farmer Press.

Bell, J. (1993). Doing your Research Project. Buckingham UK: Open University Press.

Britzman, D. (1986). Cultural myths in the making of a teacher: biography and social structure in teacher education. Harvard Educational Review, 56 (4), 442-446.

Budd Rowe, M. (1996). Mounting and maintaining an elementary school science program: What supervisors can learn from research, In J. Rhoton \& P. Bowers (Eds.), Issues in Science Education (pp. 162-166). Arlington VA: National Science Teachers Association. Butt, R., D. Raymond, G. McCue, \& L. Yamagishi (1992). Collaborative autobiography and the teacher's voice. In I. F. Godson (Ed.), Studying Teachers' Lives (pp. 51-98). London: Routledge. 
Bybee, R. \& T. Mau (1986). Science and technology related global problems: An international survey of science educators. Journal of Research in Science Education, 23 (7), 599-618.

Charmaz, K. (2000). Grounded theory: Objectivist and constructivist methods. In N. K. Denzin \& Y. S. Lincoln (Eds.), Handbook of Qualitative Research (2 ${ }^{\text {nd }}$ ed.) (pp. 509535). Thousand Oaks, CA: Sage.

Charmaz, K. (2006). Constructing Grounded Theory: A Practical Guide through Qualitative Analysis. London: Sage.

Clark, C. M., \& P. L. Peterson (1986). Teachers' thought processes. In M. C. Wittrock (ed.), Handbook on Research in Teaching (pp. 255-296). New York: Macmillan.

Cobern, W. \& Loving, C. (2000). Scientific worldviews: A case study of four high school science teachers. Electronic Journal of Science Education, 5 (2),1-26.

Cole, A. L. (1990). Personal theories of teaching: Development in the formative years. The Alberta Journal of Educational Research, 36 (3), 203-222.

Dadds, M. (1995). Passionate Enquiry and School Development: A story about teacher action research. London: The Falmer Press.

Davies, D., \& M. Rogers (2000). Pre-service primary teachers' planning for science and technology activities: influences and constraints. Research in Science and Technological Education, 18 (2), 215-225.

Drever, E. (2003). Using semi-structured interviews in small-scale research: $A$ teacher's guide. The SCRE Centre: University of Glasgow.

Eick, C. \& C. Reed (2002). What makes an inquiry-oriented science teacher? The influence of learning histories on student teacher role identity and practice. Science Education, 86 (3), 401-416. 
Enyedy, N., Goldberg, J., Welsh, K. (2006). Complex Dilemmas of identity and practice. Science Education, 90, 68-93.

Ezzy, D. (2002). Qualitative analysis: Practice and innovation. London: Routledge.

Foster, P. (1996). Observational Research, In R. Sapsford and V. Jupp (eds), Data Collection and Analysis (pp.57-93). Newbury Park CA: SAGE.

Fysh, R. \& K. Lucas (1998). Religious beliefs in science classroom. Research in Science Education, 28 (4), 399-427.

Glaser, B. G. (1978), Theoretical Sensitivity. Mill Valley, CA: The Sociology Press.

Glaser, B. G., \& A. L. Strauss (1967). The Discovery of Grounded Theory: Strategies for Qualitative Research, Chicago: Aldine.

Goldkuhl, G. \& S. Cronholm (2003). Multi-Grounded theory; adding theoretical grounding to grounded theory. In Proceedings of the 2nd European Conference on Research Methods in Business and Management (2ECRM), Reading UK, 20-21 March.

Hamilton, M., \& V. Richardson (1995). Effects of the culture in two schools on the process and outcomes of staff development. Elementary School Journal, 95, (4), 367-385.

Johnson, K. (1992). The relationship between teachers' beliefs and practices during literacy instruction for non-native speakers of English. Journal of Reading Behavior, 24 (1), 83-108.

Kagan, D. (1992). Implications of research on teacher belief. Educational Psychologis, 27 (1), 65-90.

Knowles, J. G. (1992). Models for understanding pre-service and beginning teachers' biographies: Illustration from case studies. In I. F. Goodson (Ed.), Studying Teachers' Lives (pp. 99-152). London: Routledge. 
Knowles, J.G. and Holt-Reynolds, D. (1991). Shaping pedagogies through personal histories in pre-service teacher education. Teachers College Record, 93, 87113.

Levitt, K. E. (2001). An analysis of Elementary teachers' beliefs regarding the teaching and learning of science. Science Education, 86 (1), 1-22.

Lichtenstein, G., M. W. McLaughlin. \& J. Knudsen (1992). Teacher empowerment and Professional knowledge. In A. Lieberman (Eds.), The Changing Contexts of Teaching (pp. 37-58). Chicago: The University of Chicago Press.

Lind, M. \& G. Goldkuhl (2005). The evolution of a business process theory - the case of a multi- grounded theory. In J. Von Beekhuyzen, L. Hellens, K. Guest, and M. Morley (Eds), Proceedings of the Conference on Qualitative Research in IT \& IT in Qualitative Research (QualIT 2005), Brisbane, Australia: Griffith University.

Lofland, J. \& L. Lofland, (1984). Analyzing social settings: A guide to qualitative observation and analysis ( $2^{\text {nd }}$ ed.), Belmont, CA: Wadsworth.

Lortie, D. (1975). Schoolteacher: A sociological study. Chicago, Illinois: University of Chicago Press.

Maslovaty, N. (2000). Teachers' choice of teaching strategies for dealing with sociomoral dilemmas in the elementary school. Journal of Moral Education, 29 (4), 429-444.

McGillicuddy-De Lisi, A. V., \& S. Subramanian (1996). How do children develop knowledge? Beliefs of Tanzanian and American mothers. In S. Harkness \& C. M. Super (Eds.), Parents' cultural belief systems: their origins, expressions, and consequences (pp. 143-168). New York: Guilford Press. 
McIntosh, N. (1995). Religion-as-Schema, with implication for the relation between religion and coping. The International Journal for the Psychology of Religion, $5(1), 1-16$.

Miles, M. B. \& A.M. Huberman (1994). Qualitative data analysis. Thousand Oaks, CA: Sage.

Nespor, J. (1987). The role of beliefs in the practice of teaching. Journal of Curriculum Studies, 19 (4), 317-328.

Olson, J. K. (1988). School world/micro-worlds: Computers and culture of the school, London: Pergamon.

Pajares, M. F. (1992). Teachers' beliefs and education research: Cleaning up a messy construct. Review of Education Research, 62 (3), 307-332.

Patton, M. Q. (2002). Qualitative Research and Evaluation Methods ( ${ }^{\text {rd }}$ ed.). Thousand Oaks, CA: Sage.

Pettigrew, A. M. (1989). Issues of time and site selection in longitudinal research on change. In J. I. Cash \& P. Lawrence (Eds.), The Information Systems Research Challenge: Qualitative Research methods (pp. 13-19). Boston MA: Harvard Business School Press.

Pinar, W. (1978). Notes on the curriculum field. Educational Researcher, 7 (8), 5-12.

Poole, M. (1996).' ...for more and better religious education', Science \& Education, $5,165-174$.

Poulson, L., Avramidis, E., Fox, R., Medwell., J. and Waray, D. (2001). The theoretical orientation of primary school literacy teachers: an exploratory study. Research Papers in Education, 16 (3), 271-292.

Richardson, V. (1996). The role of attitude and beliefs in learning to teach. In J. Sikula, T. J. Buttery \& E. Guyton (Eds.), Handbook of research on teaching education (pp. 102-119). New York: Macmillian. 
Richardson, V. (1997). Constructivist teaching and teacher education: theory and practice, in: V. Richardson (Ed.), Constructivist Teacher Education: building new understandings (pp. 3-14). London, Falmer.

Richardson, V. (2003). Pre-service teachers' beliefs. In J. Raths \& A. McAninch (Eds.), Teacher Beliefs and Classroom Performance: the impact of teacher education (pp. 1-22). USA: Information Age Publishing Inc.

Rubba, P. A. \& Harkness, W. L. (1993). Examination of pre-service and in-service secondary science teachers' beliefs about Science-technology-society interactions. Science Education, 77 (4), 407-431.

Schoenfeld, A.H. (1998) Toward a theory of teaching-in-context, Issues in Education, 4(1), 1-94.

Sexton, S. S. (2004). Prior Teacher Experiences Informing How Post-Graduate Teacher Candidates See Teaching and Themselves in the Role as the Teacher. International Education Journal, 5 (2), 205-214.

Shulman, L. S. (1987). Knowledge and teaching: foundation of the new reform. Harvard Educational Review, 57 (1), 1-22.

Stem, P. (1980), Grounded theory methodology: its uses and processes, Image, 12, (1), 20-33.

Strauss, A. \& Corbin, J. (1998). Basics of qualitative research: Grounded theory procedures and techniques $\left(2^{\text {nd }}\right.$ Ed.), Thousand Oaks, CA: Sage.

Talbert, J. E. \& McLaughlin, M. W. (1993). Understanding teaching in context, In: M.W. McLaughlin \& J. E. Talbert (Eds.), Teaching for understanding (pp. 162206). San Francisco: Jossey-Bass.

Tsai, C. (2001). A science teacher's reflections and knowledge growth about STS instruction after actual implementation. Science Education, 86 (1), 23-41. 
Wenger, E. (1998). Communities of Practice: learning, meaning and identity. Cambridge, UK: Cambridge University Press.

Woods, P. (1987). Life histories and teacher knowledge, In J. Smyth (Ed.), Educating teachers changing the nature of pedagogical knowledge (121-135). London: The Falmer Press.

Yerkes, K. (2004). Exploring Teacher Identity: A Yearlong Recount of Growing from Student to Teacher. Retrieved, May 14, 2005, from: http://www.ed.psu.edu/englishpds/inquiry/projects/yerkes04.htm.

Zeichner, K. (1980). Myths and realties field-based experiences in pre-service teacher education. Journal of Teacher Education, 31 (6), 45-47. 
1

2

3

4

5

6

7

8

9

10

11

12

13

14

15

16

17

18

19

20

21

Theory generation stage

- Inductive coding

- Conceptual refinement

- Building categorical structures

- Theoretical coding

Theory diagrams

$\checkmark$

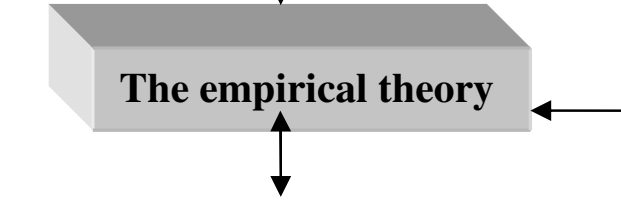

Explicit grounding stage

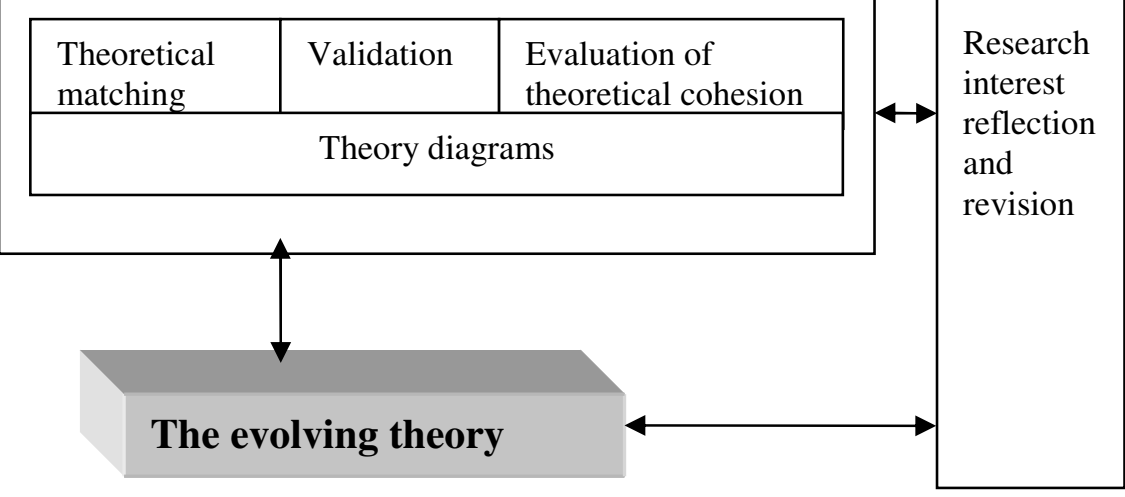

Figure 1. Procedures for generating the Personal Religious Beliefs model using Multi-Grounded Theory 


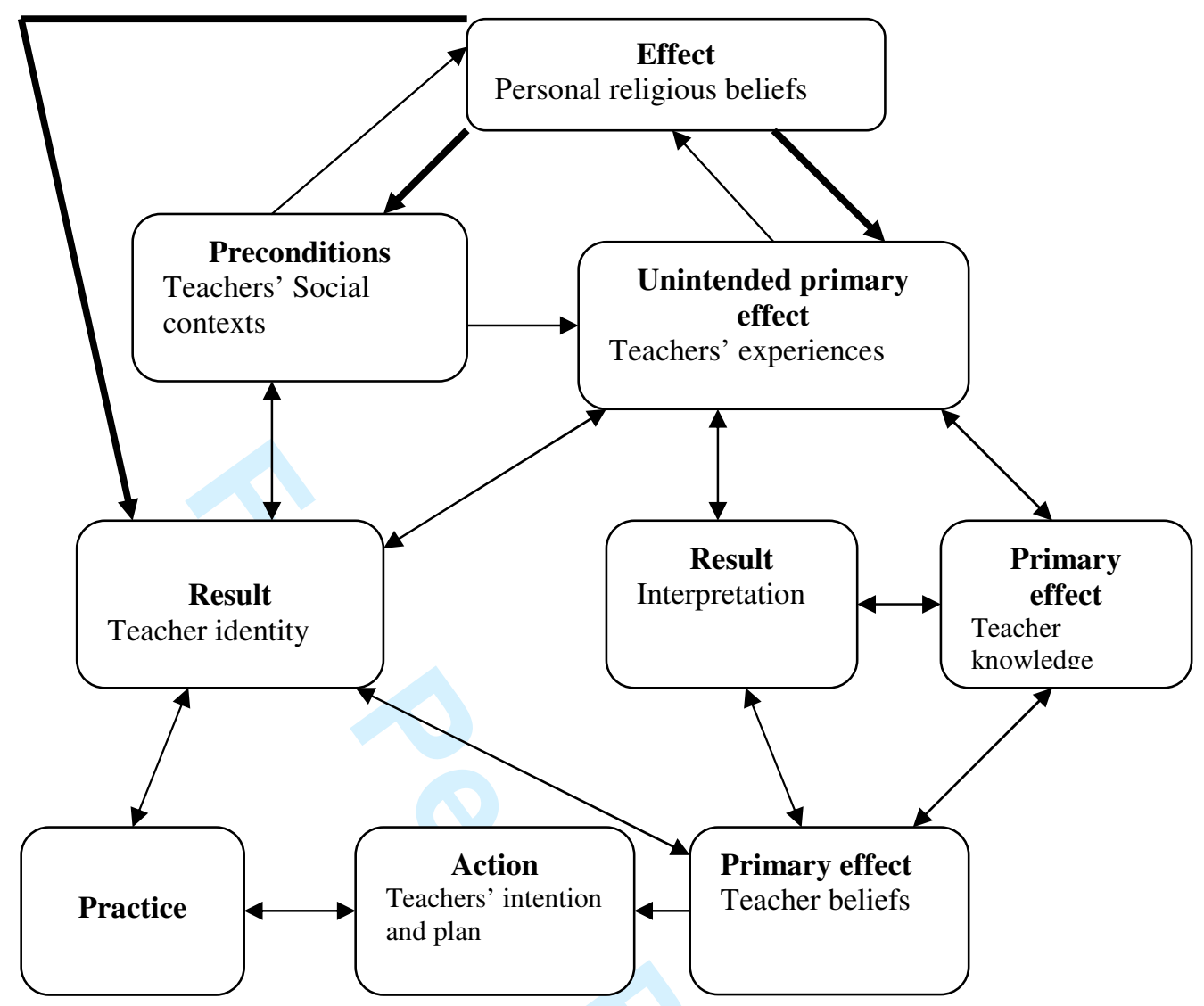

Figure 2. A 'Theory diagram' illustrating the sequence of the main categories 'empirical theory' 


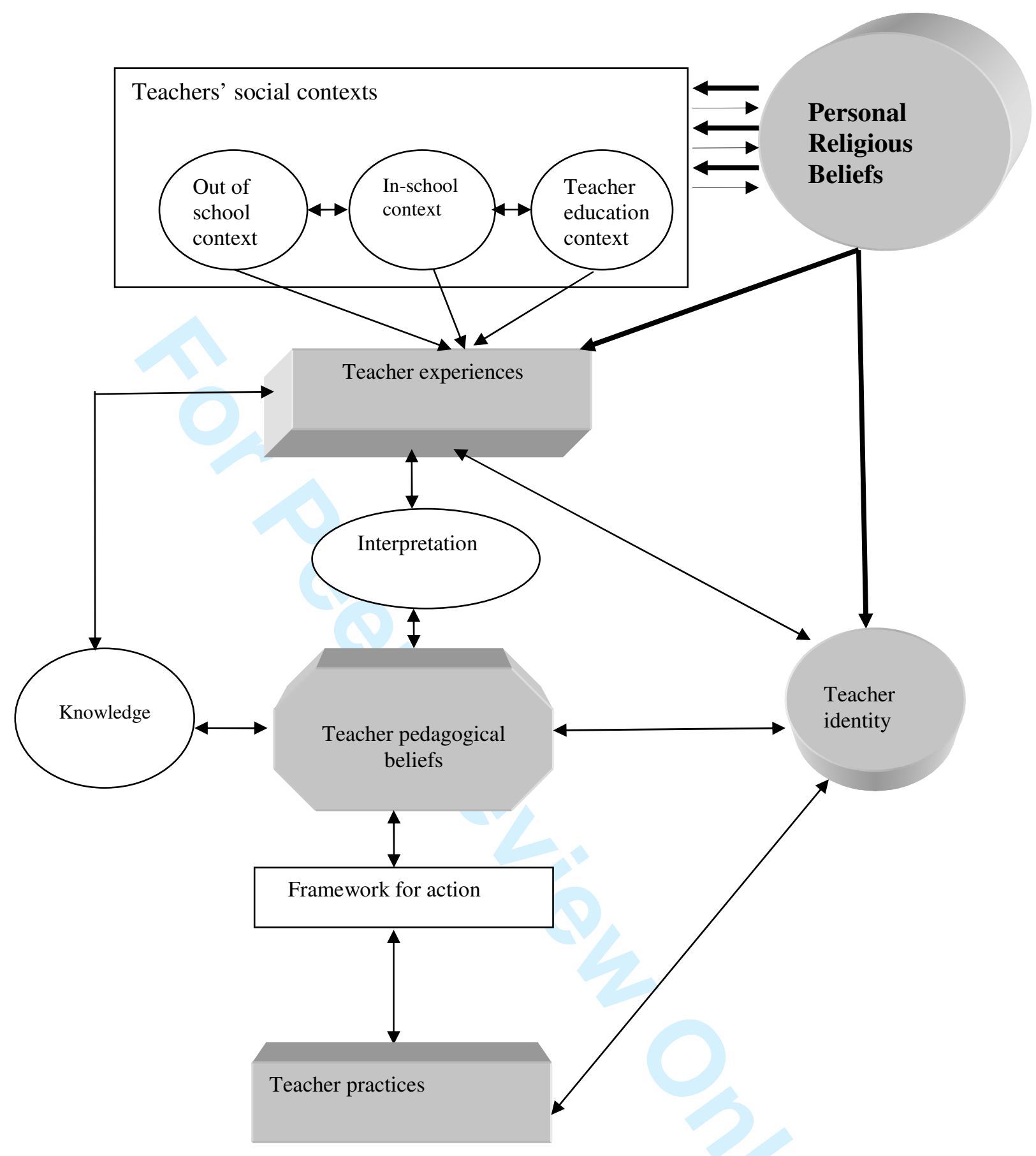

Figure 3. Personal Religious Beliefs (PRB) Model 


\section{Table 1. The Secular Education System in Egypt}

\section{University, higher and intermediate institutes}

\begin{tabular}{|l|l|l|l|}
\hline Secondary stage & $\begin{array}{l}\text { General secondary } \\
\text { schools (age 15-18) }\end{array}$ & $\begin{array}{l}\text { Technical secondary } \\
\text { schools (age 15-18) }\end{array}$ & Grade 10-12 \\
\hline $\begin{array}{l}\text { Basic education } \\
\text { (Compulsory) }\end{array}$ & Preparatory stage (age 12-15) & Grade 7-9 \\
\cline { 2 - 3 } & Primary stage (age 6-12) & Grade 1-6 \\
\hline
\end{tabular}

Table 2. Emergence of the theoretical coding 'Personal Religious Beliefs'

\begin{tabular}{|c|c|c|}
\hline Inductive coding 'Open coding' & Conceptual refinement & $\begin{array}{l}\text { Building categorical structures 'Axial } \\
\text { coding' }\end{array}$ \\
\hline Science as a creation of God & $\begin{array}{l}\text { Teacher religious understanding of } \\
\text { the sources of science }\end{array}$ & \multirow[t]{4}{*}{ Personal Religious epistemology } \\
\hline Islamic view of science & $\begin{array}{l}\text { Teachers' religious beliefs are } \\
\text { reflected in how they understand } \\
\text { science }\end{array}$ & \\
\hline $\begin{array}{l}\text { Gaining knowledge as an approach to } \\
\text { God }\end{array}$ & $\begin{array}{l}\text { The aim of any studying is to } \\
\text { approach God }\end{array}$ & \\
\hline Stable religion & Teachers enact their Islamic belief & \\
\hline $\begin{array}{l}\text { Qur'an as starting point for scientific } \\
\text { research }\end{array}$ & $\begin{array}{l}\text { Understanding Qur'an precedes } \\
\text { studying science }\end{array}$ & \multirow[t]{9}{*}{$\begin{array}{l}\text { Personal Religious scientific-view of } \\
\text { science }\end{array}$} \\
\hline Discovering science by Qur'an & $\begin{array}{l}\text { Starting searching science should } \\
\text { start from study Qur'an }\end{array}$ & \\
\hline Science as wandering around nature & Studying science can be anywhere & \\
\hline Moral principle in searching science & $\begin{array}{l}\text { Teachers reflect their religious } \\
\text { principles }\end{array}$ & \\
\hline Qur'anic guide to science & $\begin{array}{l}\text { Teachers' religious condition for } \\
\text { searching in science }\end{array}$ & \\
\hline Moral principle in searching science & $\begin{array}{l}\text { Teachers' religious moral as a } \\
\text { framework of gaining science }\end{array}$ & \\
\hline Muslim scientists & $\begin{array}{lll}\begin{array}{l}\text { Teachers' emphasis on the } \\
\text { characteristics of scientists }\end{array} & \\
\end{array}$ & \\
\hline Changeable science & $\begin{array}{l}\text { Teachers' interpretation of the reality } \\
\text { science }\end{array}$ & \\
\hline Abusing the nature & $\begin{array}{l}\text { Teachers' reflection of Islamic- } \\
\text { scientific responsibility toward the } \\
\text { nature }\end{array}$ & \\
\hline $\begin{array}{l}\text { Science content as effective } \\
\text { spirituality }\end{array}$ & $\begin{array}{l}\text { Science content as effective } \\
\text { spirituality }\end{array}$ & \multirow[t]{3}{*}{ Religious view of curriculum } \\
\hline Cloning is destructive for society & $\begin{array}{l}\text { Teachers' religious understanding of } \\
\text { cloning }\end{array}$ & \\
\hline Islamic science curriculum & $\begin{array}{l}\text { Teachers view of the development of } \\
\text { he science curriculum }\end{array}$ & \\
\hline
\end{tabular}




\begin{tabular}{|c|c|c|}
\hline $\begin{array}{l}\text { Religious orientation of Science } \\
\text { content }\end{array}$ & $\begin{array}{l}\text { Teachers view of the integration } \\
\text { between science and religion }\end{array}$ & \\
\hline $\begin{array}{l}\text { Explaining the supernatural of God } \\
\text { by science }\end{array}$ & Spiritual aim if science & \multirow[t]{6}{*}{ Religious view of the aim of science } \\
\hline Wondering about nature in Qur'an & $\begin{array}{l}\text { Teachers' religious reflection of the } \\
\text { physical laws of the nature }\end{array}$ & \\
\hline $\begin{array}{l}\text { Wondering about ourselves body in } \\
\text { Qur'an }\end{array}$ & $\begin{array}{l}\text { Teachers' religious understanding of } \\
\text { the concept of creation }\end{array}$ & \\
\hline Science guide to a good Muslim & $\begin{array}{l}\text { Religious attitude toward the role of } \\
\text { science }\end{array}$ & \\
\hline Science-religion war & $\begin{array}{l}\text { Teachers' interpretation of } \\
\text { relationship between science } \\
\text { religion }\end{array}$ & \\
\hline Qur'anic motivation of science & $\begin{array}{l}\text { Teachers' interests of science by } \\
\text { influence of religion }\end{array}$ & \\
\hline Islamic responsibility & $\begin{array}{l}\begin{array}{l}\text { Teachers' efforts to enact the } \\
\text { religious principles. }\end{array} \\
\end{array}$ & \multirow[t]{2}{*}{$\begin{array}{l}\text { Personal interpretation of religious } \\
\text { view }\end{array}$} \\
\hline $\begin{array}{l}\text { Contradictions in science not in } \\
\text { Qur'an }\end{array}$ & $\begin{array}{l}\text { Teachers' knowledge about science } \\
\text { and about the scientific processes }\end{array}$ & \\
\hline $\begin{array}{lll}\text { Simplifying } & \text { controversial } & \text { issues } \\
\text { religiously } & & \\
\end{array}$ & 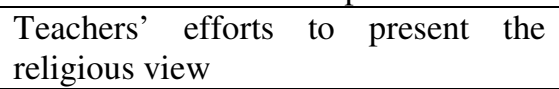 & \multirow[t]{10}{*}{$\begin{array}{l}\text { Religious view of teaching/learning } \\
\text { science }\end{array}$} \\
\hline $\begin{array}{l}\begin{array}{l}\text { Religious orientation of } \\
\text { content }\end{array} \\
\end{array}$ & $\begin{array}{l}\text { Teachers' efforts to present the } \\
\text { religious view }\end{array}$ & \\
\hline $\begin{array}{l}\text { Religion as a guide for teacher } \\
\text { education }\end{array}$ & $\begin{array}{l}\text { Teachers' saturation of the religious } \\
\text { principles }\end{array}$ & \\
\hline Biased-religious views & $\begin{array}{l}\text { Teachers' efforts to present the } \\
\text { religious view }\end{array}$ & \\
\hline Presenting science in Qur'an & $\begin{array}{l}\begin{array}{l}\text { Teachers' effort to present the } \\
\text { religious view }\end{array} \\
\end{array}$ & \\
\hline Islamic view of co-operation & $\begin{array}{l}\text { Teachers' intervention of the morals } \\
\text { and values based on religion }\end{array}$ & \\
\hline $\begin{array}{l}\text { Qur'anic verses as a guide for } \\
\text { controversial issues }\end{array}$ & $\begin{array}{l}\text { Teachers' religious perspective of } \\
\text { teaching controversial issues }\end{array}$ & \\
\hline Islamic approach of teaching & $\begin{array}{ll}\begin{array}{l}\text { Teachers' religious reflection of } \\
\text { teacher science }\end{array} & \\
\end{array}$ & \\
\hline $\begin{array}{l}\text { Qur'anic approach for teaching } \\
\text { controversial issues }\end{array}$ & $\begin{array}{l}\begin{array}{l}\text { Teachers' religious reflection of } \\
\text { teacher science }\end{array} \\
\end{array}$ & \\
\hline Helping in Islam & Teachers' religious motivation & \\
\hline Expressing the right view & Evaluative role of teacher & \multirow{3}{*}{$\begin{array}{l}\text { Characteristics of Muslim science } \\
\text { teachers }\end{array}$} \\
\hline Changing the students' attitudes & Evaluative role of teacher & \\
\hline Facilitator & Teachers' action & \\
\hline
\end{tabular}

